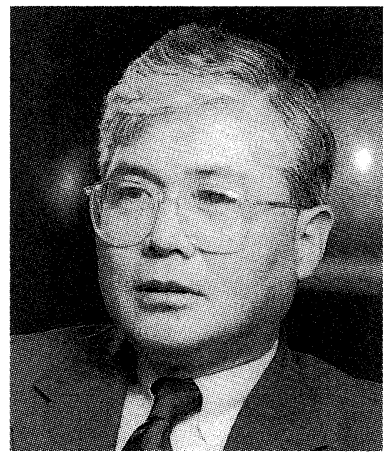

\title{
岸 義人教授に文化功労者顕彰
}

\author{
理化学研究所 $\cdot$ 主任研究員
中田
}

この度, ハーバード大学岸義人教授が天然物有機化学 の分野における優れた功績に対し 2001 年度文化功労者 として顕彰されました。有機合成化学協会の会員とし て，また先生にご指導いただいた門下生の一人として心 から扮祝い申し上げます。

岸先生は, 1961 年名古屋大学理学部を卒業後, 同大 学院において平田義正教授のもとで天然物有機化学の研 究を開始されました。1966 年博士号を取得後, 同研究 室助手となられ, 直ちにハーバード大学 Woodward 教 授のもとで 2 年間博士研究員としてビタミン $\mathrm{B}_{12}$ の全合 成研究に従事し重要な役割を果たしました。帰国後, 1969 年名古屋大学農学部助教授に就任しフグ毒テトロ ドトキシンの全合成に着手されました。1971年秋, 名 古屋で開催された天然有機化合物討論会の 2 日目朝一番 の講演は，その全合成がまさに直前に完成したことを発 表するものであり, 会場は大きな感動と万雷の拍手に包 まれたものでした。その後多くの挑戦にも拘わらず，い まだ唯一の合成であることは，全合成の最高傑作の一つ であることを如実に示すものです。

これらの成果をもって，1974 年若くしてハーバード 大学教授として招かれました。その後の活躍は，まさ に, 天然物合成の最高峰であったWoodward 教授の選 んだ人としての期待にふさわしいもので, 特異な構造を 有する抗生物質グリオトキシン，貝毒サキシトキシン， 抗腫瘍性抗生物質マイトマイシンなどの最初の全合成を 次々と達成しました。さらに 1977 年, いまだ何人も挑 戦していない分野であった多くの不斉中心を有するポリ エーテル系抗生物質の合成研究を開始されました。その 全合成を目指して, 当時極めて困難とされていた鎖状系 での立体制御という課題に取り組み, キレーション制御 下，あるいは優位コンホメーション下での立体選択的反 応などを開発し, ラサロシド $\mathrm{A}$, モネンシンの全合成を $1-2$ 年という極めて短期間に達成し, その後爆発的に 進展した鎖状立体制御という新たな方法論の有用性を先 駆的に示されました。

私自身この時期, 先生のもとで研究する機会を得まし
たが，その合成研究はそれぞれ未解決な重要問題の解明 に対する強い動機と興味から始まり, 合成の意義を感じ させるものでした。また，その研究を通じて困難を乗り 越える不屈の精神を学び, 先生自身の何にも勝る化学へ の興味，献身の姿勢に強く心うたれたものです。

その後, 1980 年恩師平田教授室での分子量 2680 , 不 斉炭素 64 個をもつ巨大分子パリトキシンとの出会いに 始まるその立体構造決定 ·全合成研究の成果は化学史に 残る金字塔と見なされるものです。未解決で残されてい た 51 個の不斉中心の立体構造決定に挑戦され，その 8 個の分解フラグメントのすべての立体異性体を化学合成 し，1982 年その全立体構造の決定に成功し, さらに 1989 年パリトキシン酸, 1994 年パリトキシン自身の全 合成を達成され, 有機合成化学の絶大な力を示されまし た。

この研究はさらに, AAL-トキシンの立体構造決定, またマイトトキシンの立体構造未決定部分の構造決定に 展開され，ユニバーサル NMR データベースの確立によ る鎖状化合物の立体構造決定という壮大な概念のもとで の研究に発展しています。最近,ての概念のもとに, 立 体構造未知の天然物をなんら分解反応, 構造誘導するこ となくモデル分子の合成と NMR データーベースの確立 により相対および絶対構造を決定できることを見事に実 証されました。この間, 全合成研究においても, ハリコ ンドリン，スポンジスタチン 1 , バトラコトキニン A, ピンナトキシン A な゙の複雑な天然物の全合成に世界 に先駆けて成功しています。

岸先生のご研究はいずれも未開拓分野を切り開きその 最前線を行くものであり，またその全合成は洗練された 気品と堂々たる風格を感じさせてくれます。先生のその 先導的研究は有機化学に多大の貢献をすると同時に, 世 界の若い研究者に独自の観点をもって研究を進展する重 要性を感じさせ，またその意欲を奮い立たせてくれるも のと信じます。

岸先生には, 今後も益々ご健康で先導的研究を進展さ れ，ご活躍されることをお祈りいたします。 